\title{
The Interplay between Regulations and Financial Stability
}

\author{
Franklin Allen ${ }^{1} \cdot$ Xian Gu ${ }^{2}$
}

Received: 27 March 2017 /Revised: 14 March 2018 / Accepted: 20 March 2018/

Published online: 18 April 2018

(C) The Author(s) 2018

\begin{abstract}
The crisis demonstrated that microprudential regulation focusing on the risks taken by individual banks is not sufficient to prevent crises. This is because it ignores systemic risk. Six types of systemic risk are identified, namely: (i) panics - banking crises due to multiple equilibria; (ii) banking crises due to asset price falls; (iii) contagion; (iv) financial architecture; (v) foreign exchange mismatches in the banking system; (vi) behavioral effects from Knightian uncertainty. We focus on the first three as they are arguably the main causes of the 2007-9 crisis and consider regulatory and other policies to counteract them.
\end{abstract}

Keywords Financial crises $\cdot$ Asset price bubbles $\cdot$ Contagion $\cdot$ Macroprudential

JEL Classification $\mathrm{G} 01 \cdot \mathrm{G} 21 \cdot \mathrm{G} 28$

\section{Introduction}

During the Crisis of 2007-9 microprudential regulation of the banking system turned out to be unable to maintain financial stability largely because it did not recognize the problem of systemic risk. This paper discusses some of the sources of systemic risk, their importance for financial stability and the policies that can be used to counter them.

Systemic risk arises from a wide range of sources including the following:

1. Panics - banking crises due to multiple equilibria

Presented at a conference on "The Interplay of Financial Regulations, Resilience, and Growth" at the Federal Reserve Bank of Philadelphia on June 16-17, 2016.

Franklin Allen

f.allen@imperial.ac.uk

Xian $\mathrm{Gu}$

xiangu@cufe.edu.cn

1 Imperial College London, London, UK

2 Central University of Finance and Economics, Beijing, China 
2. Banking crises due to asset price falls

3. Contagion

4. Financial architecture

5. Foreign exchange mismatches in the banking system

6. Behavorial effects from Knightian uncertainty

We focus on the first three of these here as they are the main causes of the Crisis of 2007-9 and then consider the regulations and other government and central bank interventions to counter them so that future crises are both less probable and likely to cause less damage when they occur.

In what follows we consider the evidence related to the recent financial crisis, as well as what we know from the theoretical literature and analysis of earlier crises. In particular we start discussing the panics and fundamental systemic risks in Section 2 and we focus on the asset price falls in Section 3. In Section 4, we analyze financial contagion, which is the cause of widespread distress in the financial system. Finally, Section 5 concludes.

\section{Banking crises: panics versus fundamentals}

Although the importance of panics in the Crisis of 2007-9 is unclear, they remain an important source of systemic risk and thus deserve some attention. Two distinct theories for the origins of banking panics have been proposed in the academic literature (see Allen et al. (2009) and Benoit et al. (2017) for surveys). One line of argument maintains that panics are undesirable events caused by random deposit withdrawals unrelated to changes in the real economy. In the seminal work by Bryant (1980) and Diamond and Dybvig (1983), for example, panics are selffulfilling events. Agents have uncertain needs for consumption and long-term investments are costly to liquidate. They deposit their endowment in a bank in exchange for a demand deposit contract, which insures them against their liquidity needs. If all depositors believe that the other depositors withdraw their funds only according to their consumption needs, then the good equilibrium arises in which the bank can satisfy all depositors' demands without liquidating any of the long term assets. If, however, depositors believe that other depositors will withdraw prematurely, then all agents find it rational to redeem their claims and a panic occurs.

The second set of theories suggests that banking crises are not random events but a natural outgrowth of the business cycle. The idea is that an economic downturn will reduce the value of bank assets, raising the possibility that banks are unable to meet their commitments. If depositors receive information about the impending downturn in the cycle, they will anticipate financial difficulties in the banking sector and try to withdraw their funds prematurely, as in Gorton (1988). This attempt will precipitate the crisis. In this case, crises are a response of depositors to the arrival of sufficiently negative information on the unfolding economic circumstances.

The empirical evidence is mixed. Friedman and Schwartz (1963) argue that the systemic risk and financial instability in the U.S. in the late eighteenth and early nineteenth century were panic-based, as evidenced by the absence of downturns in the relevant macroeconomic time series prior to the crises. In contrast, Gorton (1988), Calomiris and Gorton (1991) and Calomiris and Mason (2003) provide a wide range of evidence that many of the crises that occurred in the U.S. in that period were fundamental-based. 
These are only highlights of the literature on banking crises and panics here. More complete surveys are provided by Gorton and Winton (2003), Allen and Gale (2007) and Freixas and Rochet (2008).

There is little doubt that fundamentals played an important role in the Crisis of 2007-9. In the following sections we will discuss the causes of the fundamental-based crisis in greater depth. Diamond and Dybvig (1983) argue that deposit insurance is an effective way of eliminating or at least reducing panics in frequency. In their model, this policy effectively eliminates the bad panic equilibrium and there is no cost to the policy since only the good equilibrium remains. However, what would be the result if we followed the recommendation of reducing runs via deposit insurance in a world where crisis could also be caused by fundamentals? The model in Diamond and Dybvig (1983) is a very simple one that excludes other types of systemic risk. The case of Ireland illustrates the perils of implementing guarantees when the real cause of the crisis is not a panic but something else. In the case of Ireland it was a bursting real estate bubble. When the Irish government imposed a blanket guarantee of bank debt in Ireland in September 2008, it eventually led to the government having to be bailed out by the EU and IMF.

An analysis of government guarantees in the presence of panics and fundamental systemic risk is contained in Allen et al. (2017a). They consider the distortions in banks' risk taking decisions caused by guarantees. Their analysis is based on a global games approach. Several surprising results are derived. First, guarantees reduce the probability of a run, taking as given the deposit contract set by the bank, but lead banks to take more liquidity risk, which in turn might lead to an increase in the probability of a run. Second, guarantees against fundamentalbased failures and panic-based runs may lead to greater efficiency than guarantees against panic-based runs alone. Finally, there are cases in which following the introduction of guarantees banks take less liquidity risk (and more solvency risk) than would be optimal.

\section{Causes of the housing price bubble}

A second type of systemic risk is due to asset price falls. There are many reasons that asset prices can fall. In this section, we focus on the causes of the housing price bubble and collapse that occurred in a number of countries.

Herring and Wachter (1999), Reinhart and Rogoff (2009) and Crowe et al. (2011) provide persuasive evidence that collapses in real estate prices, either residential or commercial or both, are one of the major causes of financial crises. In many cases these collapses occur after bubbles in real estate prices that are often created by loose monetary policy and excessive availability of credit. When the bubble bursts, the financial sector and the real economy are adversely affected.

The 2007-9 crisis provides a good example of this. Allen and Carletti (2009) argue that the main trigger of the crisis was that there was a bubble in real estate in the U.S. and in a number of other countries such as Ireland and Spain. When the bubble burst in the U.S., many financial institutions experienced severe problems because of the collapse in the securitized mortgage market. The problems in this market caused the financial system to malfunction in numerous ways. Problems then spread to the real economy. Similarly, in other countries. Figure 1 shows the movement in property prices in the U.S., Ireland, and Spain. Figures 2 and 3 show the ten primary Case-Shiller cities in the U.S. and a number of European countries, respectively. It can be seen that in most of the countries, but not all, house prices rose significantly and then 


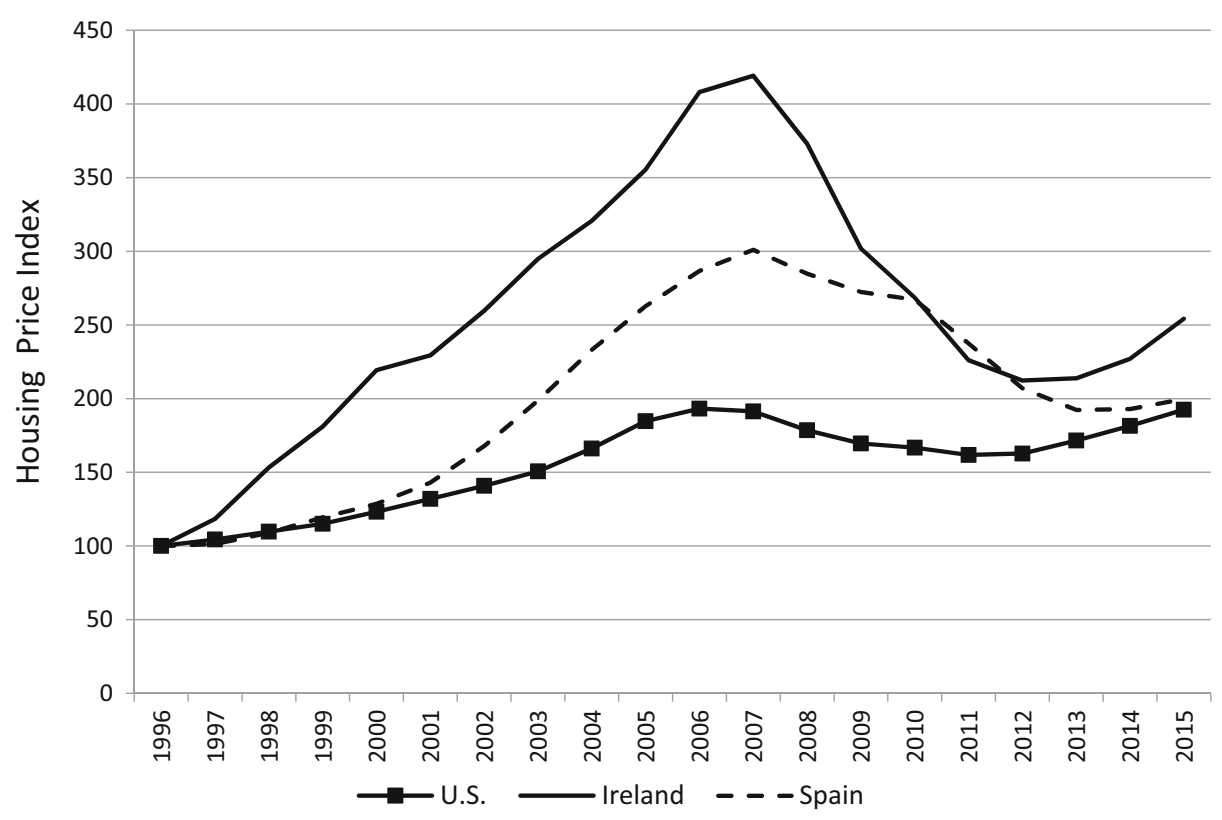

Fig. 1 Housing prices in Ireland, Spain and the U.S.

dropped. An important issue is what led to these price movements. A number of authors have suggested that the real estate bubble in these countries was the result of loose monetary policy and global imbalances that led to excessive credit availability. Central banks, in particular in the U.S., set very low interest rates during the period 2003-2004 to avoid a recession after the tech bubble in 2000 and the 9/11 terrorist attacks in 2001 at a time when house prices were already rising quite fast. As argued by Taylor (2008), these levels of interest rates were much lower than in previous U.S. recessions relative to the economic indicators at the time captured by the "Taylor rule". In such an environment of low interest rates, people in the U.S. started to borrow and buy houses to benefit from their growing prices. Unlike stock prices where returns follow random walks, returns on housing are positively serially correlated as found by Case

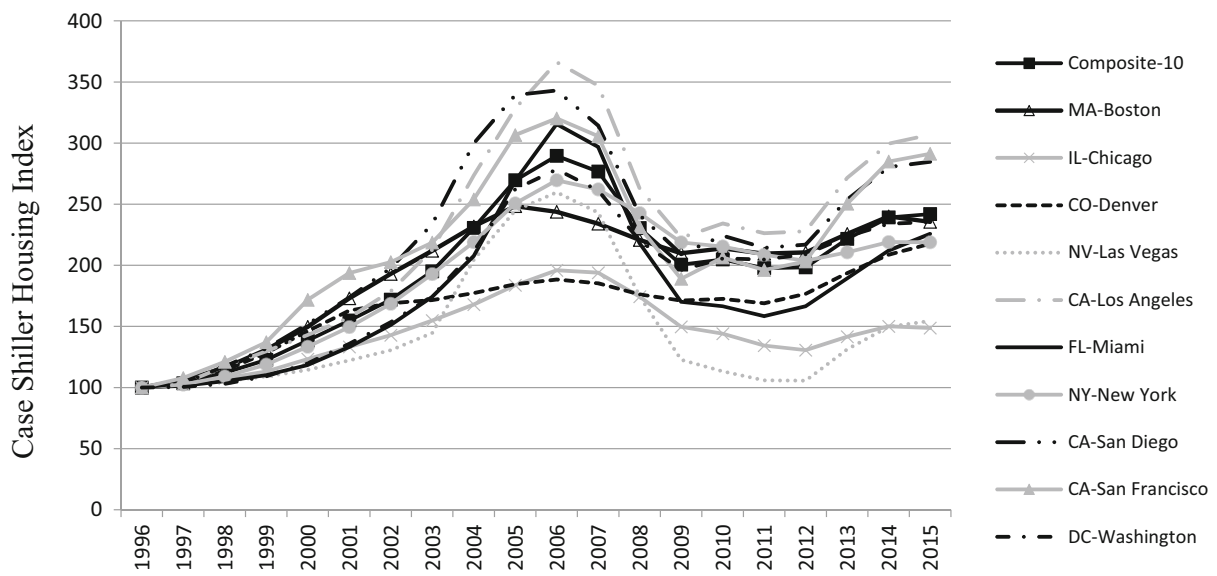

Fig. 2 Nominal housing prices in different U.S. cities 


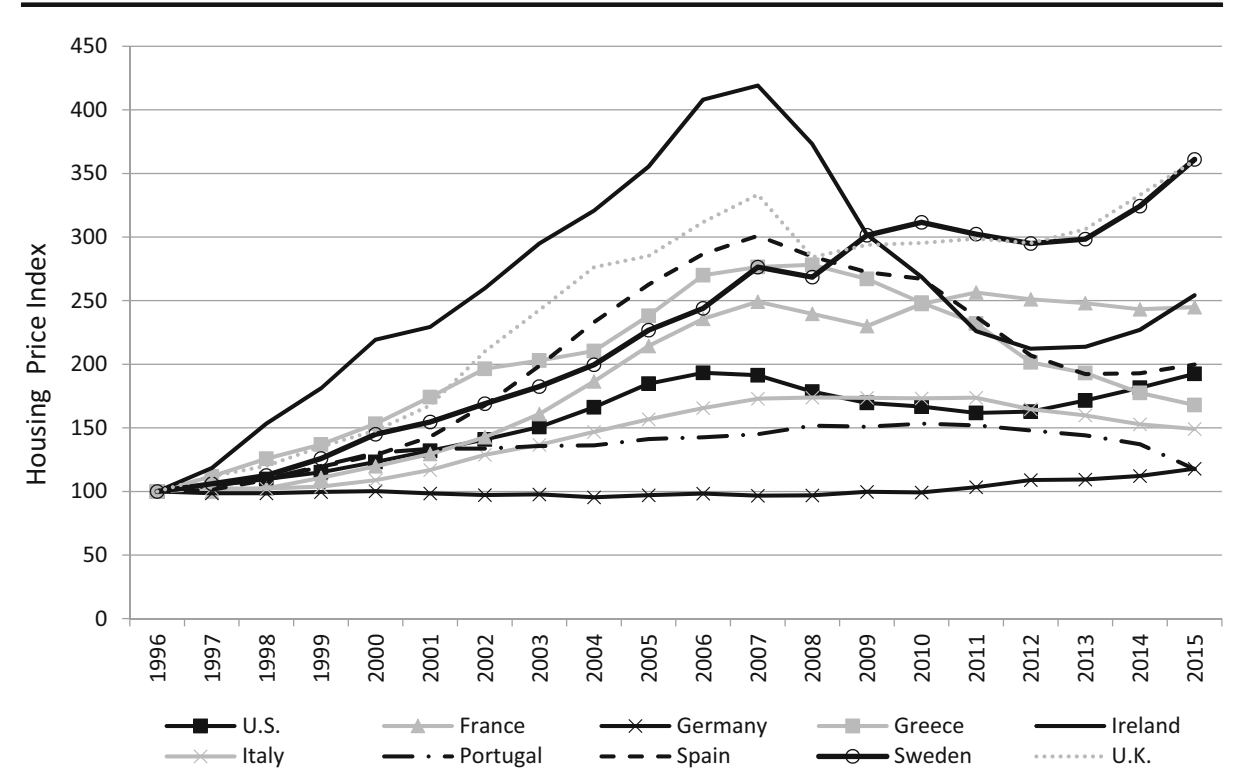

Fig. 3 Nominal housing prices in U.S. and various European countries

and Shiller (1989), Englund et al. (1998), and Glaeser and Gyourko (2007). This means that by lowering interest rates significantly below the current rate of house price appreciation, the Fed effectively created a profitable opportunity to buy property. Bleck and Liu (2017) document that too much liquidity injection to the economy resulting from loose monetary policy can distort the credit market and result in real estate bubbles. The reasoning is that real estate's flexibility makes it good collateral that can easily be repurposed if the borrower defaults. As a result it attracts greater investment by passive investors, who must trust managers more and lose less value with real estate than with factories (see Glaeser (2016)). Other public policies such as the tax deductibility of interest rates on mortgage contributed further to the housing boom.

There are also some other commonly discussed causes to the housing price bubble. For example, some argue that it was the mandate of federal government that banks and GSEs support low- and moderate-income borrowers; some others argue that the government's subsidy of mortgage debt in terms of tax deduction and implicit guarantee of the GSEs were responsible (see, e.g. Rajan (2010); Hernandez-Murillo et al. (2014)). Another explanation is the expansion of mortgage loans to subprime borrowers and of low doc mortgages and high loan-to-value mortgages. However, these alternative explanations could not be the complete story because they cannot explain the simultaneous bubbles in Ireland and Spain.

As Fig. 1 showed, these two countries also had very large run ups in property prices. According to Taylor (2008), these countries also had loose monetary policies relative to the Taylor rule. Spain, which had one of the largest deviations from the rule, also had the biggest housing boom as measured by the change in housing investment as a share of GDP. Other countries in the Eurozone such as Germany did not have a housing boom. Their inflation rates and other economic indicators were such that for them the European Central Bank's interest rates did not correspond to a loose monetary policy.

As Allen and Gale (2000a, 2007) have argued, asset price bubbles are also caused by growth in credit. During the crisis, credit expanded rapidly in the countries with a loose 
monetary policy due to the presence of global imbalances. Several Asian countries had accumulated large amounts of foreign exchange reserves since the late 1990s. There are a number of reasons behind this accumulation. Allen and Carletti (2009) argue that the Asian countries affected by the crisis of 1997 started accumulating reserves in response to the tough conditions that the International Monetary Fund imposed on them in exchange for financial assistance. The motivations for the reserve accumulation of China, which is the largest holder, are probably more complex than this. Beside the precautionary reason, China started accumulating reserves to avoid allowing its currency to strengthen and damage its exports as well as to increase its political power. The accumulated reserves were mostly invested internationally. Much of it was invested in U.S. dollars in debt securities such as Treasuries, and Fannie and Freddie mortgage-backed securities either directly or indirectly. Large global imbalance might not trigger financial instability if the surplus country makes equity investments in the deficit country, especially if the funds are recycled as foreign direct investments. However, for the Asian countries, given their objective of holding excess reserves to reduce reliance on the IMF, they would want to hold reserves in relatively liquid assets that are likely to retain their value in bad times rather than equity assets. Moreover, it actually became difficult in particular for the Chinese to make equity investment in foreign countries. For example, in 2005 when the China National Offshore Oil Corporation (CNOOC), a government-owned company, wanted to buy Unocal Corporation the transaction was blocked by the U.S. authorities on the grounds that Unocal was a strategic company. This happened on a number of other occasions when Chinese companies attempted to make cross-border acquisitions. Therefore, China ended up having investments mainly in debt instruments. In this case, the large supply of debt in the U.S. helped to drive down lending standards to ensure that there was enough demand for debt from house buyers and other borrowers. Additionally, funds did not only flow to the U.S., Spain and Ireland also ran large current account deficits, with debt increasing rapidly.

Some recent studies argue that the degree of leverage in the banking system is not a necessary condition for an asset price bubble to cause financial instability. For example, Feroli et al. (2014) document that financial market disruptions, such as the market "tantrums" seen during the summer of 2013 where risk premiums inherent in market interest rates fluctuated widely, can arise without any leverage or actions taken by leveraged financial intermediaries.

The bursting of a bubble has a clear effect on the stability of the financial sector as documented in Herring and Wachter (1999) and Reinhart and Rogoff (2009). In the crisis of 2007-9, for example, the sudden drop in some financial asset prices starting in the summer 2007 triggered by the fall in real estate prices and the large volatility that followed worsened the balance sheets of financial institutions significantly and froze several financial markets including also the normally stable interbank market.

The financial crisis then spread to the real sector. The bursting of a bubble can create direct damaging effects on the real economy. In the current crisis, for example, the bursting of the property bubble in Spain led to a doubling of unemployment without the financial sector being much affected, at least initially. This was thanks to strict financial regulation and the use of some macroprudential instruments such as countercyclical loan loss reserve ratios. The fact that the bursting of a bubble can affect both the financial and the real sector significantly underlines the importance of preventing bubbles.

The discussion above has highlighted real estate as a source of systemic risk in the financial sector. We next discuss macroprudential regulatory measures and policies that could be put in place to deal with the identified sources of systemic risk. What is most important is that the new macroprudential regulation deals with systemic risk and no longer only with the risk of 
failure of single financial institutions. The current crisis has clearly shown that the microprudential approach to financial regulation does not suffice to prevent systemic crises.

In order to avoid future crises, it is of the utmost importance to try to be able to predict real estate and other asset price bubbles and prevent their emergence. In an important early paper, Borio and Lowe (2002) argue that while it is difficult to predict asset price bubbles and in particular property bubbles, it is not impossible. They provide evidence that rapid credit growth combined with large increases in real estate prices can lead to financial instability. In low inflation environments they suggest that inflationary pressures can first appear in asset prices rather than in the prices of goods and services. They argue that in such cases it may be appropriate to use monetary policy to "lean against the wind" to prick asset bubbles and to preserve financial and monetary stability.

It may be possible and desirable to do this in economies with a high degree of homogeneity as in small countries like Sweden or possibly the U.K. However, doing this may be difficult for political reasons. In particular when such policies are first introduced, it may be difficult to explain why it is worth causing a recession to burst a property bubble. Svensson (2016) has argued that in fact the cost-benefit analysis of this kind of policy suggests they are not worthwhile even in economies such as that of Sweden.

The problem is more complicated in heterogeneous economies like the U.S., China and the Eurozone. Different regions within these economies differ in terms of economic fundamentals and the rate of property price increases. Using interest rates to prick bubbles will not be so desirable because this will adversely affect the areas that do not have bubbles. The events in the Eurozone constitute a clear example. The interest rate policy followed by the European Central Bank was correct for countries like Germany where there was no bubble but it was inappropriate for Spain, where it contributed to the creation of the property bubble. A tighter policy may have been effective for preventing the bubble in Spain but at the cost of a recession or at least slower growth in some of the other countries.

When interest rates cannot be used, it may be better to use other forms of macroprudential regulation to prevent bubbles. One example would be limits on loan-to-value ratios that would be lowered as property prices increase at a faster pace. This can be effective for residential property but may be difficult to enforce for commercial property. The reason is that firms may be able to use pyramids of companies that effectively increase leverage. Another measure is to have property transfer taxes that are greater the higher is the rate of property price increases. Another, perhaps more direct, measure is to impose restrictions on real estate lending in certain regions.

Crowe et al. (2011) consider the effects of these types of macroprudential measures to eliminate real estate booms. They have been tried in several Asian countries including, Hong Kong, Korea, and Singapore. They appear to be effective in the short term but not in the medium and long term.

Saying that monetary policy should not be used to prick bubbles in larger economies or in monetary unions where countries have different economic conditions does not imply that monetary policy should not be constrained. Loose monetary policy is arguably one of the main causes for the emergence of bubbles, as the crisis of 2007-9 has shown. One of the most important macroprudential measures should be constraining monetary policy so that it does not trigger bubbles. Excessively low levels of interest rates should not be implemented, particularly when real estate prices are already rising. A possible way to do this is to set up a check and balance mechanism. The idea behind this is to introduce some form of accountability for central banks. Another, more drastic, way to do it is to give central banks the clear mandate to prevent asset bubbles. 
As discussed earlier in this section, the second major cause of bubbles is excessive credit. During the recent crisis excessive credit emerged because of large global imbalances. To prevent bubbles in the future, it is important to solve this problem. While it is individually advantageous for countries to self-insure by accumulating reserves, this is an inefficient mechanism from a global perspective.

As argued above and in Allen and Hong (2011), the accumulation of reserves by the Asian countries was at least partly a response to the harsh policies that the IMF imposed on a number of countries during the Asian crisis in the late 1990s. Part of the problem was the fact that East Asian countries were not well represented in the senior staff of the IMF. It is therefore important to reform the governance structure of the IMF and of the other international organizations to ensure that the Asian countries receive equal treatment when they need financial help. This would reduce the need of these countries to accumulate reserves as a self-insurance mechanism.

To reduce the large accumulation of reserves by China, other measures are necessary, however. For example, senior Chinese officials have proposed having a global reserve currency. This has the advantage that reserves can be created initially without large transfers of resources and the attendant risk of a crisis. All countries could be allocated enough reserves in the event of a crisis so that they could survive shocks. The problem is that an international institution like the IMF would need to implement the currency. There would then be again the issue of whether all countries, and in particular the Asian ones, are properly represented in the governance process of this institution. A more likely medium term scenario is that the Chinese Rmb becomes fully convertible and joins the U.S. dollar and the euro as the third major reserve currency. With three reserve currencies there would be more competition and more scope for diversification of risks. China itself would have little need of reserves so the reliance on the U.S. dollar would be significantly reduced. This is perhaps one of the most practical solutions to the global imbalances problem which had triggered the credit expansion before the crisis of 2007-9, as discussed earlier in this section. The Chinese have taken some steps in this direction. They have encouraged the settlement of trade in Rmb. They have also allowed the issue of Rmb bonds by Western companies such as McDonalds in Hong Kong. Of course, the most important aspect of being a reserve currency is full convertibility. That is still some way off for the Rmb, and this is the sense in which this solution to the global imbalances problem is a medium term one. ${ }^{1}$

One of the major problems in the crisis was that many securitized securities appear to have been mispriced when the markets were illiquid for at least some time during the height of the crisis from 2007 to 09 (see Bank of England (2008)). One explanation is that this is due to cash-in-the-market-pricing and limits to arbitrage (Allen and Carletti (2008a); Allen et al. (2006)). In times of crisis, the interaction of institutions and markets can lead to situations

\footnotetext{
${ }^{1}$ Despite stricter capital controls starting from the end of 2016 aimed at preventing volatility of the Rmb exchange rate, financial openness, especially Rmb "internationalization" and capital account liberalization at a steady pace, still appears to be the ultimate goal of Rmb exchange rate reform. This was confirmed by the 2017 National Financial Work Conference in Beijing, one of the most important working conferences in the financial sector, chaired by President Xi in the summer and the on-going opening up of interbank bond market (the launch of the Mainland-HK bond connect). It is perhaps not that surprising that the long-term trend would be accompanied by some short-run policies/measures to manage the systemic risk in the development of financial system. How to manage financial risks, especially systemic risks, is one of the major tasks in the development of financial system. For more details, see: http://english.gov.cn/news/top_news/2017/07/16 /content_281475730862558.htm; for more discussions on RMB exchange rate reform, see, e.g., Allen et al. (2017b).
} 
where prices in illiquid markets do not reflect future payoffs but rather reflect the amount of cash available to buyers in the market. When mark-to-market accounting is used, the volatility of asset prices directly affects the asset value. In such a situation when funding liquidity is tight, market participants become reluctant to take on positions, which further lowers market liquidity. In other words, market liquidity and funding liquidity can be mutually reinforcing, leading to liquidity spirals (Bunnermeier and Pedersen (2009)). Another explanation to mispricing is asymmetric information and in particular adverse selection (see, e.g. Brunnermeier (2009)). Financiers become especially careful about accepting collateral as they worry that the assets left as collateral are only the poor and less valuable assets.

The problem is to design policies that allow this problem to be corrected. This was the origin of the TARP program in the U.S. The idea was that by buying large amounts of the toxic assets the Treasury could restore the functioning of the market. In practice they were unable to actually implement the program. This type of direct intervention seems problematic to say the least. Clearly there are significant political economy issues. There are also issues of whether such a scheme could actually restore the market to proper functioning. This is one of the most important areas of macroprudential policies. As yet no convincing solutions have been suggested.

Given the lack of an immediate solution to this problem, what should governments do? One of the major problems is that recent reforms have ensured that financial institutions mark their assets to market. In normal times this is undoubtedly the best system. Financial institutions have traditionally used historic cost accounting for many of their assets. This system has the disadvantage that it allows institutions to hide falls in asset values for significant periods of time. A good example is the S\&L crisis in the U.S. in the 1980's. This kind of episode encouraged the move to mark-to-market accounting by the IASB and U.S. FASB (see, e.g., Allen and Carletti (2008a) and Plantin et al. (2008)). The divergence between asset prices, particularly those of securitized products, and apparent fundamentals in the current crisis meant that mark-to-market accounting came under severe criticism by financial institutions and was relaxed by the FASB under political pressure from Congress.

How should the advantages and disadvantages of mark-to-market accounting be balanced? As long as markets are efficient, mark-to-market accounting dominates. However, if as during times of crisis they cease to be efficient, market prices do not provide a good guide for regulators and investors. The key issue then becomes how to identify whether financial markets are working properly or not. Allen and Carletti (2008b) suggest that when market prices and model based prices diverge significantly (more than $2 \%$ say), financial institutions should publish both. If regulators and investors see many financial institutions independently publishing different valuations they can deduce that financial markets may no longer be efficient and can act accordingly.

\section{Causes of widespread distress in the financial system}

One source of systemic risk that does appear to have been important during the recent financial crisis is contagion (see Helwege and Zhang (2016)). This refers to the possibility that the distress of one financial institution propagates to others in the financial system thus leading ultimately to a systemic crisis. Central banks often use the risk of contagion to justify intervention, especially when the financial institution in distress is big or occupies a key position in particular markets. This is the origin of the term "too big to fail." The crisis 
abounds with examples of this. For example, Bernanke (2008) argued that the takeover of Bear Stearns by J.P. Morgan arranged by the Federal Reserve Bank in March 2008 was justified by the likelihood that its failure would lead to a whole chain reaction where many other financial institutions would have gone bankrupt. There would have been contagion through the network of overnight tri-party repo market that Bear Stearns was part of and other investment banks relied on.

When Lehman Brothers failed in September 2008, it was presumably expected by the Federal Reserve that its failure would not generate contagion. In fact, there was contagion, but it was quite complex. The problem spread first to the Prime Reserve Money Fund due to its exposure to Lehman's debt securities, which further triggered the run on the other money market funds so the government had to intervene rapidly by providing a guarantee of all money market mutual funds. In addition, the failure of Lehman led to a loss of confidence in many financial firms as investors feared that other financial institutions might also be allowed to fail. More importantly, it occurred half a year after the bailout of Bear Stearns, which created the impression that systemically large investment banks were too-big-to-fail. ${ }^{2}$ Therefore, when a large investment bank, Lehman was allowed to fail, it called into question that which financial firms were implicitly insured, further leading to a widespread loss in confidence. After the failure of Lehman, the volumes in many important financial markets fell significantly, and there was a large spillover into the real economy. World trade collapsed and in trade based economies such as Germany and Japan GDP fell significantly in the fourth quarter of 2008 and the first quarter of 2009. This dramatic fall in GDP in many countries underlines the importance of the process of contagion.

Despite its importance, our understanding of the effects of contagion risk is still limited. The academic literature has provided a few explanations of the mechanisms at play, but much work is still needed. The literature on contagion takes a number of approaches (see Glasserman and Young (2016) and Benoit et al. (2017) for surveys). In looking for contagious effects via direct linkages, early research by Allen and Gale (2000b) studied how the banking system responds to contagion when banks are connected under different network structures. It is shown that incomplete networks are more prone to contagion than complete structures. Following research focused on network externalities created from individual bank risk and some others applied network techniques to the study of contagion in financial systems. The main result in this theoretical literature is that greater connectivity reduces the likelihood of widespread default. However, shocks may have a significantly larger impact on the financial system when they occur. Two important recent contributions are Elliott et al. (2014) and Acemoglu et al. (2015). Acemoglu et al. (2015) argue that when the magnitude of negative shocks affecting financial institutions are beyond a certain point, dense interconnections serve as a mechanism for the propagation of negative shocks and lead to a more fragile financial system. Another approach focusing on the existence and nature of equilibria with contagion are Eisenberg and Noe (2001) and Glasserman and Young (2015). By considering default by firms that are part of a single clearing mechanism, Eisenberg and Noe (2001) find that even unsystematic, nondissipative shocks to the system will lower the value of the financial system and may lower the value of the individual systemic firms. Glasserman and Young (2015) further reinterpret the Eisenberg-Noe framework as a valuation model rather than a clearing

\footnotetext{
${ }^{2}$ In March 2008 when Bear Stearns' refinancing difficulties became severe, the Federal Reserve concluded that Bear Stearns was too large (with almost $\$ 400$ billion in assets) and too interconnected to be allowed to enter into bankruptcy and arranged a takeover by J. P. Morgan. For more details, see White (2014).
} 
model and find that contagion cannot be generated solely through spillover losses in a network of payment obligations. For contagion to occur, either the initial shock must be large compared to the net worth of the infected node, or the net worth of the infected nodes must be small enough. Gai and Kapadia (2010), Amini et al. (2016) and Battiston et al. (2016) adopt mathematical approaches to the spread of crises through networks. Babus (2016) considers the endogenous formation of networks.

Wagner (2010), Ibragimov et al. (2011) and Allen et al. (2012) consider a second type of contagion where systemic risk arises from common asset exposures. Diversification is privately beneficial but increases the likelihood of systemic risk as portfolios become more similar. The use of short term debt can lead to a further significant increase in systemic risk.

The recent crisis has shown that asset price volatility can also be an important form of contagion. Prices drop when banks have to sell their assets in response to a negative shock. These sales depress asset prices and may have negative spillovers on other banks in various ways. For example, low asset prices may affect the solvency of other financial institutions that need to raise liquidity in the market by selling assets (e.g., Allen and Carletti (2006)). Because of the low prices, banks in need of liquidity raise little money from the asset sales. This forces banks to sell larger quantities of assets with the consequence of further deterioration in asset prices. A similar mechanism holds when mark-to-market accounting is in use (Allen and Carletti (2008a)). In an integrated financial system this form of contagion can easily transmit shocks internationally, in particular through large institutions operating cross border or on global financial markets.

The key issue is how likely contagion is in practice. A substantial strand of empirical literature is based on the first type of approach where financial institutions have direct linkages resulting from the mutual claims they have on one another. Most of these papers use balance sheet information to estimate bilateral credit relationships for different banking systems and estimate the stability of the interbank market by simulating the breakdown of a single bank. This literature is surveyed in Upper (2011) and Benoit et al. (2017). Overall the main finding in the empirical literature is that contagion is unlikely. However, there are a number of reasons for caution in accepting this result and concluding that policymakers need not worry about contagion between banks. The first is that they do not model price effects of bankruptcy. Cifuentes et al. (2005) have argued that these price effects are the main transmission mechanism for contagion. As Upper (2011) points out, they also rely on the initial shock being confined to a single bank. If there is an initial shock that affects several banks simultaneously, then this can also lead to contagion being more likely.

As argued above, contagion is arguably one of the most important problems of systemic risk. Despite its importance, it is not yet fully understood how contagion can occur, and there is very little work done so far on how to stop it. The channels for contagion are multiple, ranging from direct linkages among banks on the interbank market or the payment system to common asset exposure.

There may be the need for several policies and regulations that address the different channels and types of contagion. Capital regulation has been the main tool for regulating banks in recent years. This has been coordinated internationally through the Basel agreements. It is the main tool for ensuring stability in the international financial system. The traditional justification in the academic literature for capital regulation has been that it is needed to offset moral hazard from deposit insurance (for examples of exceptions, see Hellman et al. (2000)). Because banks have access to low cost funds guaranteed by the government, they have an incentive to take significant risks. If the risks pay off they receive the upside, while if they do 
not the losses are borne by the government. Capital regulation is needed to offset the incentives for banks to take risks as it ensures that shareholders will lose significantly. Moreover, capital acts as a buffer to absorb losses, thus making banks more resilient to shocks and losses and perhaps most importantly reducing the risk of contagion. On the other hand, considerable empirical evidence shows that both banks and nonfinancial firms have bankruptcy costs (James 1991; Acharya et al. 2007; Glover 2016). When deposit and equity markets are segmented and bankruptcy costs exist for banks, equity capital is costly relative to deposits and banks hold a positive amount of equity capital as a way to reduce such social costs that would arise from failure (See, Allen et al. 2015).

There is a long standing debate on how much capital banks should hold. The crisis of 2007-9 and the discussions behind the proposals for a new regulatory framework have highlighted the difficulties embodied in new regulations. The starting point of the discussion is that capital is a more costly form of funding than debt so that, if unregulated, banks minimize the use of capital. Thus there is the need for a regulation that forces banks to hold minimum levels. The same argument is typically assumed in the academic literature (see, for example, Gorton and Winton (2003)).

Modeling the cost of equity finance for financial institutions is one of the major problems in designing capital regulation. The first issue is whether equity is in fact more costly than debt. If that is so, the second issue is whether equity is more costly only in the financial industry or also in all other industries. It is the case that financial institutions hold approximately $10 \%$ capital while industrial companies operate with 30-40\% equity. Understanding the reasons for this large difference in capital structures is of crucial importance to design capital regulation appropriately.

One simple answer as to why capital is privately more costly is that in many countries debt interest is tax deductible at the corporate level but dividends are not. It is not clear why this is and whether this should be the case. There does not seem to be any good public policy rationale for having this deductibility. It seems to have arisen as an historical accident. When the corporate income tax was introduced interest was regarded as a cost of doing business in the same way that paying wages to workers was a cost. However, from a modern corporate finance perspective, this is not the correct way to think about it. Equity and debt are just alternative ways of financing the firm. If tax deductibility is why there is a desire to use debt rather than equity, then the simple solution is to remove it. If without deductibility financial institutions are willing or can be induced through regulation to use more equity, then financial stability would be considerably enhanced. He and Matvos (2016) provide another justification for corporate debt subsidy by documenting that debt tax shield can induce firms to increase their debt levels and further shorten the wasteful competition for survival in a declining industry. In this case, debt subsidy can improve social welfare. However, there has been very few evidence on this in financial industry. Using an exogenous change in tax legislation in Belgium in 2006 that created a tax shield for equity and therefore reduced the relative tax advantage of debt, Schepens (2016) shows that a reduction in tax discrimination between debt and equity leads to better capitalized financial institutions, as well as a significant reduction in risk taking for low capitalized banks.

Other possible rationales for the high cost of equity are agency problems within the firm. According to this rationale, the cost of equity is that it does not provide the correct incentives to shareholders or managers to provide the right monitoring. High leverage is needed to ensure this. For example, the fear that deposits or short-term debt might be withdrawn or not renewed could lead managers to act more in line with the preferences of creditors and other investors in 
financial institutions. However there is little empirical evidence that this is in fact a severe problem in the banking sector. For example, leverage in private equity and venture capital firms, where the agency problem seems much greater, is typically less than in banks. Admati et al. (2013) argue that for financial institutions, leverage can create significant frictions and governance problems that distort the lending, investment as well as the subsequent funding decisions that show quite an opposite effect to "disciplining" managers. Moreover, these frictions could be exacerbated in the presence of implicit guarantees, which also blunt the potential monitoring effect. The crisis of 2007-9 also appears to contradict the notion that debt helps to ensure the right monitoring by shareholders or managers.

A final point concerns the reason why financial institutions hold so little capital relative to other industries. The tax deductibility argument cannot explain this difference, as it holds for all industries. A more plausible explanation is that debt in the financial industry is implicitly subsidized through government guarantees and bailouts. If this is why financial institutions rely so much on debt, then it is necessary to remove guarantees and create credible enforcement mechanisms, that is, proper resolution procedures. Without this, banks will continue minimizing the amount of capital they hold and society will bear the costs of this through increased financial instability. Many countries, most notably those in the Eurozone, have reformed resolution procedures but they have yet to be tested in a crisis.

In the current debates on capital regulation two main proposals have been put forth. The first one concerns countercyclical capital regulation. The second concerns the use of hybrid instruments in the form of contingent convertible debt (CoCos).

One of the most widely suggested macroprudential policies is countercyclical capital regulation. The idea is that during "normal times" banks and other financial institutions can accumulate capital reserves and buffers that will allow them to survive serious shocks to the financial system. These measures are related to countercyclical loan reserves that have been implemented by the Bank of Spain for some time. Spanish banks did accumulate loan reserves in the period before the crisis, and this helped them to weather the crisis better than they otherwise would. This experience suggests that countercyclical capital ratios may be helpful. However, they did not prevent the credit boom in Spain and the bubble in property prices, so not too much reliance should be placed on them.

It has been widely suggested that banks should issue convertible debt that could be converted into equity in the event of a crisis. The issue of this kind of security by Royal Bank of Scotland and Lloyds in the U.K. and Unicredit in Italy are an example. With such hybrid debt instruments, banks can obtain the benefits of tax deductibility of their interest payments in good times. In bad times, by committing creditors to provide equity through conversion (or a write-down) of the claims, CoCos can have two main advantages. First, it is not necessary for banks to raise capital in difficult times as it would already be in place. Second, contingent capital allows the sharing of losses with debtholders. This would also have a disciplinary role and would induce bank managers to behave more prudently. Chen et al. (2017) document that by setting the contractual trigger for conversion sufficiently high, CoCos can be effective in mitigating debt overhang. Nevertheless, the relative complexity of these hybrid instruments has also raised some questions about whether they can function as expected and whether they might have unintended consequence. Critics have argued that there is no sense in which hybrid securities are cheaper than equity from society's perspective and increasing equity level would be more effective than relying on hybrid securities (See Admati et al. (2013)). Moreover, conversion might also involve a complete write down if the bank becomes financially distressed. 
Another way to stabilize markets and avoid contagion is to have a combination of public and private financial institutions. This is the case for example in Chile, where Banco Estado is a publicly owned commercial bank that competes with private sector banks. In times of crisis, such a bank can expand and help stabilize the market as all market participants know that it is backed by the state and will not fail. That's what many central banks have effectively been doing by buying large quantities of commercial paper. These central banks have become like large commercial banks. But the officials in charge of central banks do not usually have much expertise in running a commercial bank or know much about credit risk. It would be better to have expertise in the public sector which allows the state to perform commercial banking functions during times of crisis. These state institutions would act as firebreaks and limit the damage that can be done by contagion.

\section{Concluding remarks}

In this paper, various types of systemic risk have been considered. The role of real estate bubbles has been particularly stressed, but there are other kinds of systemic risk as well. Regulations, particularly macroprudential regulations, represent one way to try to deal with this type of systemic risk and create financial stability. However, a whole range of other kinds of intervention in addition to regulation are necessary. Regulation alone is not sufficient to create financial stability.

Acknowledgments We are grateful to participants, and particularly to our discussant Joe Peek and an anonymous referee, and the editor for comments and suggestions that have greatly improved the paper.

Open Access This article is distributed under the terms of the Creative Commons Attribution 4.0 International License (http://creativecommons.org/licenses/by/4.0/), which permits unrestricted use, distribution, and reproduction in any medium, provided you give appropriate credit to the original author(s) and the source, provide a link to the Creative Commons license, and indicate if changes were made.

\section{References}

Acemoglu D, Ozdaglar A, Tahbaz-Salehi A (2015) Systemic risk and stability in financial networks. Am Econ Rev 105:564-608

Acharya V, Bharath S, Srinivasan A (2007) Does industry-wide distress affect defaulted firms? Evidence from creditor recoveries. J Financ Econ 85:787-821

Admati A, DeMarzo P, Hellwig M, Pfleiderer P (2013) Fallacies, irrelevant facts, and myths in the discussion of capital regulation: why bank equity is not socially expensive. Stanford University Rock Center for Corporate Governance Working Paper No. 161

Allen F, Carletti E (2006) Credit risk transfer and contagion. J Monet Econ 53:89-111

Allen F, Carletti E (2008a) Mark-to-market accounting and liquidity pricing. J Account Econ 45:358-378

Allen F, Carletti E (2008b) Should financial institutions mark to market? Bank Fr Finance Stab Rev 12:1-6

Allen F, Carletti E (2009) An overview of the crisis: causes, consequences and solutions. Int Rev Finance 10:1-27

Allen F, Gale D (2000a) Bubbles and crises. Econ J 110:236-255

Allen F, Gale D (2000b) Financial contagion. J Polit Econ 108:1-33

Allen F, Gale D (2007) Understanding Financial Crises, Clarendon Lecture Series in Finance. Oxford University Press, Oxford

Allen F, Hong J (2011) Why are there large foreign exchange reserves? The case of South Korea. Korean Soc Sci J 38(2): 1-33

Allen F, Litov L, Mei J (2006) Large investors, price manipulation and limits to arbitrage: an anatomy of market corners. Rev Finance 10(4):645-693

Allen F, Babus A, Carletti E (2009) Financial crises: theory and evidence. Annu Rev Financ Econ 1:97-116 
Allen F, Babus A, Carletti E (2012) Asset commonality, debt maturity and systemic risk. J Financ Econ 104:519-534

Allen F, Carletti E, Marquez R (2015) Deposits and bank capital structure. J Financ Econ 118:601-619

Allen F, Carletti E, Leonello A, Goldstein I (2017a). Government guarantees and financial stability. Working paper, University of Pennsylvania

Allen F, Gu X, Qian J (2017b). People's Bank of China: history, current operations and future outlook. Imperial College Working Paper

Amini H, Cont R, Minca A (2016) Resilience to contagion in financial networks. Math Financ 26:329-365 ISSN:0960-1627

Babus A (2016) The formation of financial networks. RAND J Econ 47:239-272

Bank of England (2008) Financial stability report, April. https://www.bankofengland.co.uk//media/boe/files/financial-stability-report/2008/may-2008.pdf?la=en\&hash=D912B602332112F5673056 CD998EC30DD9AE07A1

Battiston S, Caldarelli G, May R, Roukny T, Stiglitz J (2016) The price of complexity in financial networks. Proc Natl Acad Sci U S A 113(36):10031-10036

Benoit S, Colliard J, Hurlin C, Perignon C (2017) Where the risks lie: a survey of systemic risk. Rev Finance 21(1):109-152

Bernanke B (2008) Opening remarks. Maintaining Stability in a Changing Financial System, Federal Reserve Bank of Kansas City, Jackson Hole Symposium, 1-12. https://www.kansascityfed. org/ /media/files/publicat/sympos/2008/bernanke031209.pdf?la=en

Bleck A, Liu X (2017) Credit expansion and credit misallocation. Journal Monet Econ. https://doi.org/10.1016/j. jmoneco.2017.09.012

Borio C, Lowe P (2002) Asset prices, financial and monetary stability: exploring the nexus. Bank for International Settlements Working Paper 114

Brunnermeier M (2009) Deciphering the liquidity and credit crunch 2007-2008. J Econ Perspect 23(1):77-100

Bunnermeier M, Pedersen L (2009) Market liquidity and funding liquidity. Rev Financ Stud 22(6):2201-2238

Bryant J (1980) A model of reserves, bank runs, and deposit insurance. J Bank Finance 4:335-344

Calomiris C, Gorton G (1991) The origins of banking panics, models, facts, and bank regulation. In: Hubbard RG (ed) Financial markets and financial crises. University of Chicago Press, Chicago, pp 109-173

Calomiris C, Mason J (2003) Fundamentals, panics and bank distress during the depression. Am Econ Rev 93: 1615-1647

Case K, Shiller R (1989) The efficiency of the market for single-family homes. Am Econ Rev 79:125-137

Chen N, Glasserman P, Nouri B, Pelger M (2017) Contingent capital, tail risk, and debt-induced collapse. Rev Financ Stud 30(11):3921-3969

Cifuentes R, Ferrucci G, Shin H (2005) Liquidity risk and contagion. J Eur Econ Assoc 3(2-3):556-566

Crowe C, Dell'Ariccia G, Igan D, Rabanal P (2011) How to deal with real estate booms: lessons from country experiences. IMF Working Paper 11/91

Diamond D, Dybvig P (1983) Bank runs, deposit insurance, and liquidity. J Polit Econ 91:401-419

Eisenberg L, Noe T (2001) Systemic risk in financial systems. Manag Sci 47(2):236-249

Elliott M, Golub B, Jackson M (2014) Financial networks and contagion. Am Econ Rev 104:3315-3153

Englund P, Quigley J, Redfearn C (1998) Improved price indexes for real estate: measuring the course of Swedish housing prices. J Urban Econ 44:171-196

Feroli M, Kashyap A, Schoenholtz K (2014) Market tantrums and monetary policy. Chicago Booth Working Paper No. 14-09

Freixas X, Rochet J-C (2008) Microeconomics of banking, 2nd edn. MIT Press, Cambridge

Friedman M, Schwartz A (1963) A monetary history of the United States, 1867-1960. Princeton University Press, Princeton

Gai P, Kapadia S (2010) Contagion in financial networks. Proc R Soc Lond A 466(2120):2401-2423

Glaeser E (2016) Real estate bubbles and urban development. NBER Working Paper No. 22997

Glasserman P, Young P (2015) How likely is contagion in financial networks? J Bank Finance 50:383-399

Glasserman P, Young P (2016) Financial networks. J Econ Lit 54(3):779-831

Glaeser E, Gyourko J (2007) Housing dynamics. Harvard Institute of Economic Research, Discussion Paper 2137, http://www.economics.harvard.edu/journals/hier2007

Glover B (2016) The expected cost of default. J Financ Econ 119:284-299

Gorton G (1988) Banking panics and business cycles. Oxf Econ Pap 40:751-781

Gorton G, Winton A (2003) Financial intermediation. In Constantinides G, Harris M, Stulz R (eds) Handbook of the Economics of Finance, Volume 1A, Chapter 8 Amsterdam, 431-552

He Z, Matvos G (2016) Debt and creative destruction: why could subsidizing corporate debt be optimal? Manag Sci 62(2):303-325

Hellman T, Murdock K, Stiglitz J (2000) Liberalization, moral hazard in banking, and prudential regulation: are capital requirements enough? Am Econ Rev 90:147-165 
Helwege J, Zhang G (2016) Financial firm bankruptcy and contagion. Rev Finance 20(4):1321-1362

Hernandez-Murillo R, Ghent A, Owyang M (2014) Did affordable housing legislation contribute to the subprime securities boom? Federal Reserve Bank of St. Louis Working Paper 005D

Herring R, Wachter S (1999) Real estate booms and banking busts: an international perspective. Wharton Financial Institutions Center Working Paper 99-27

Ibragimov R, Jaffee D, Walden J (2011) Diversification disasters. J Financ Econ 99:333-348

James C (1991) The losses realized in bank failures. J Financ 46:1223-2170

Plantin G, Sapra H, Shin H (2008) Marking-to-market: panacea or pandora's box? J Account Res 46:435-460

Rajan R (2010) Bankers have been sold short by market distortions. Financial Times, June 2nd. https://www.ft. com/content/9daee5e0-6e70-11df-ad16-00144feabdc0

Reinhart C, Rogoff K (2009) This time is different: eight centuries of financial folly. Princeton University Press, Oxford and Princeton

Schepens G (2016) Taxes and bank capital structure. J Financ Econ 120:585-600

Svensson L (2016) Cost-benefit analysis of leaning against the wind: are costs larger also with less effective macroprudential policy? IMF Working Paper WP/16/3. https://www.imf.org/external/pubs/ft/wp/2016 /wp1603.pdf

Taylor J (2008) The financial crisis and the policy responses: an empirical analysis of what went wrong. Stanford University Working Paper

Upper C (2011) Simulation methods to assess the danger of contagion in interbank markets. J Financ Stab 7:111125

Wagner W (2010) Diversification at financial institutions and systemic crises. J Financ Intermed 19:333-354

White L (2014) The basics of "too big to fail". In: Schultz PH (ed) Perspectives on Dodd-Frank and Finance. MIT Press, Cambridge, pp 25-42 